\title{
First report of false smut caused by Graphiola phoenicis on Indian wild date (Phoenix sylvestris) from India
}

\author{
S., Mahadevakumar ${ }^{1}$, Y.S., Deepika ${ }^{2,3}$, N., Lakshmidevi ${ }^{3}$ and K.N., Amruthesh ${ }^{1 *}$ \\ ${ }^{2}$ Applied Phytopathology Laboratory, Department of Studies in Botany, University of Mysore, Manasagangotri, Mysuru-570 \\ 006, Karnataka, India \\ ${ }^{2}$ Department of Studies in Botany, University of Mysore, Manasagangotri, Mysuru-570 006, Karnataka, India \\ ${ }^{3}$ Department of Studies in Microbiology, University of Mysore, Manasagangotri, Mysuru-570 006, Karnataka, India \\ "Corresponding author Email: dr.knamruthesh@botany.uni-mysore.ac.in \\ (Submitted on February 10,2020; Accepted on April 29, 2020)
}

\begin{abstract}
Phoenix sylvestris grown widely in southern parts of Karnataka showing characteristic false smut disease symptoms was noticed recently. The symptoms on foliar pinnae include small yellowish lesions on both sides of the leaf blade with brown to black globular or cylindrical and irregular sori. They were subepidermal in origin with hard and dark coloured outer wall shaving ostiole. Mature sori whitish to creamy, thread like and filaments emerging from the ostiole were observed. Micro-morphological studies revealed that, the associated fungus was Graphiola phoenicis, a member of basidiomycetous fungi. So far there is no report on the occurrence of false smut on wild date palm (P. sylvestris) in India.
\end{abstract}

Keywords: False smut, Phoenix sylvestris, Graphiola phoenicis, new host record.

\section{INTRODUCTION}

Indian date palm (Phoenix sylvestris) is native to India and southern parts of Pakistan and also widely distributed in Myanmar, Nepal, Bhutan, Bangladesh, Mauritius, China and Sri Lanka. It grows naturally and also cultivated around homesteads, farmland periphery and in marginal lands along the roadside, canals, and even on fallow land (Jain et al., 2018). Fruits are known for nutritional values as they are rich source of carbohydrate, phenols, amino acids, flavonoids, tannins, alkaloids, terpenoids, dietary fibers, essential vitamins and minerals and for their medicinal properties as antipyretic, cardiotonic, laxative, diuretic and antioxidant (Jain et al., 2018). In India, it is growing as wild plant in Karnataka, Rajasthan, Gujarat, Himachal Pradesh and Haryana(Newton et al., 2013).

During the field survey, occurrence of false smut was observed on $P$. sylvestris. Severe infection reduced tree growth and resulted in premature death of leaves. Therefore, the present study was aimed at identification of the false smut associated with $P$. sylvestris in India and compared with $P$. dactylifera as the previous record lack the technical details related to the description of Graphiola phoenicis (pictorial descriptions and spore measurements).

\section{MATERIALS AND METHODS}

A survey on dry regions of southern Karnataka was conducted during June-October 2018. A characteristic false smut disease on Indian date palm, Phoenix sylvestris in wild habitat near Doddamaragowdanahally $\left(12^{\circ} 17.05^{\prime} \mathrm{N}, 076^{\circ} 30.58^{\prime} \mathrm{E}\right)$ and Pandavapura $\left(12^{\circ} 30.28^{\prime} \mathrm{N}, 076^{\circ} 41.59^{\prime} \mathrm{E}\right)$ were recorded. Further, for comparison studies, false smut associated with date palm were also studied. The diseased leaves with symptoms of false smut found on $P$. dactylifera from Devagalli $\left(12^{\circ} 14.17^{\prime} \mathrm{N}, 076^{\circ} 34.59^{\prime} \mathrm{E}\right)$ and Basavanahalli $\left(12^{\circ} 21.05^{\prime} \mathrm{N}, 076^{\circ} 54.14^{\prime} \mathrm{E}\right)$, regions of Mysore district (Karnataka) were collected. These leaves were examined for morphological identification of the pathogen (Sepulveda et al., 2017). Characteristic fruiting bodies were examined under stereo-binocular research microscope (Carl Zeiss Stereo Discovery: V12, Germany) and microscopic images of spermatia were captured using a compound research microscope (QUASMO, Eco-star series, Ambala, India). The size and shape of fruiting bodies were measured using micrometry and compared between $P$. sylvestris and $P$. dactylifera.

Collections Examined: Phoenix sylvestris - India, Karnataka, Doddamaragowdanahally, Mysuru, Mahadevakumar and Amruthesh, June 18, 2018, UOM20181; Karnataka, Mandya, Pandavapura (Kunthi betta), Mahadevakumar and Amruthesh July 3, 2018, UOM20185.

Phoenix dactylifera- Karnataka, Mysuru, Devagalli, Mahadevakumar and Amruthesh, August 15, 2018, UOM201810; Karnataka, Mysuru, Bannur, Basavanahalli, Mahadevakumar and Amruthesh, October 02, 2018, UOM201812.

\section{RESULTS AND DISCUSSION}

In the present study, a total of 18 wild date palms were observed in Doddamaragowdanahally of which leaves of seven trees were found associated with false smut disease. In Pandavapura region (Kunthi betta, a hilly region), a total of 32 wild date palms were observed of which 27 were associated with the false smut. A total of eight date palms were diseased in Devagalli and Basavanahalli. The characteristic symptoms on $P$. dactylifera and $P$. sylvestris are presented in Fig. 1. The initial disease symptoms include the appearance of small yellow or brown to black globular cylindrical and irregular sori on either side of leaf blades. The pathogen produced the fruiting bodies (sori) on spots. Sori (0.3-1.5 mm diam.) were subepidermal in origin with dark and hard outer walls. Abundant sori were also observed on the leaves of apical regions of the host plants. Mature sori appeared as white to creamy thread like filaments which emerged through the ostiole of each sorus. The filaments (2-5 $\mathrm{mm}$ in length) upon closer examination, 


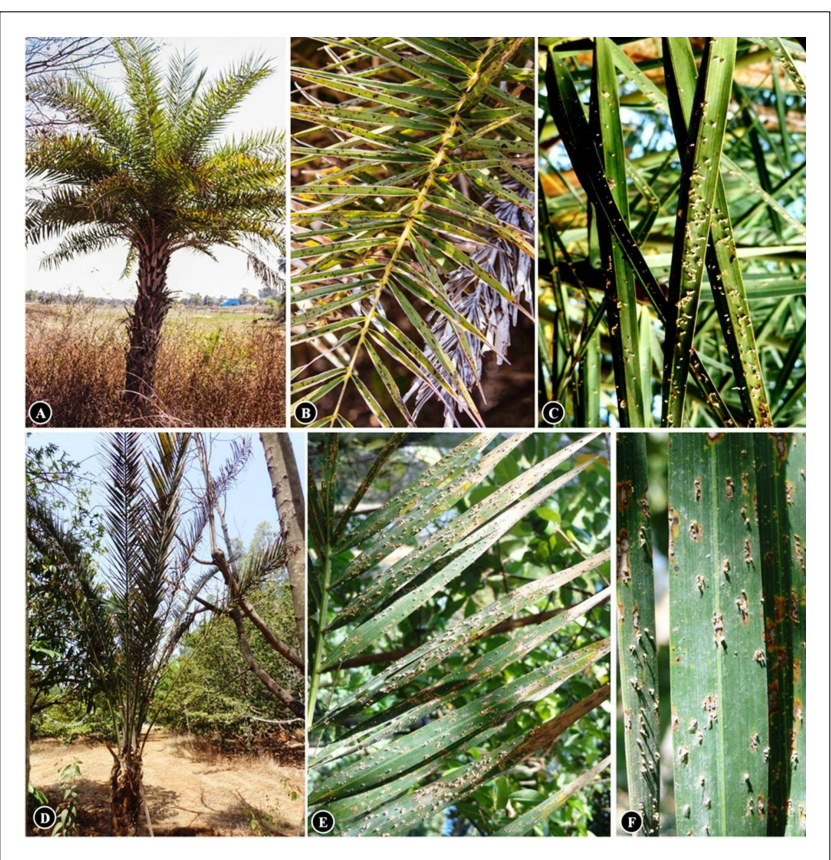

Fig. 1. Graphiola false smut associated with Phoenix sylvestris and $P$. dactylifera. A: $P$. sylvestris palm affected with false smut disease; B-C: leaf blades affected with false smut showing false smut sori; D: Graphiola false smut on $P$. dactylifera collected from Mysuru; E F. False smut sori developed on the leaves of date palm.

revealed the exudation of powdery yellow spore mass. The spores $(2-7 \mu \mathrm{m})$ were spherical to ellipsoidal, with a smooth hyaline wall (Fig.2). Based on the symptomatology and morphological characteristics, the associated pathogen was identified as Graphiola phoenicis (Moug. ex. Fr.) Poit. (Cole, 1983; Djerbi, 1983; Sepulveda et al., 2017). The disease symptoms and spots of Graphiola phoenicis were more prevalent and can be differentiated easily from other palm diseases. This disease is also known as Graphiola leaf spot and palm leaf pustule (Abbas and Abdulla, 2004).

Dates have been an important basic food for several cultures over thousands of years and they are still consumed widely all over the world, especially in the Middle East and North Africa (Yahia and Kader, 2011). P. sylvestris, popularly known as Indian wild date palm is also referred as Sugar date palm, Toddy palm and silver date palm. It is very popular among landscapers due to its low maintenance and striking appearance besides the traditional medicinal value for the treatment of abdominal complaints, fevers, loss of consciousness, constipation, toothache, nervous debility and helminthiasis and in heart complaints (Rao et al., 1970; Jain et $a l ., 2018)$. However, the palm is affected by various diseases. The most common diseases associated with date palms are leaf spot disease by Pestalotiopsis species, Anthracnose by Colletotrichum species and many others.

The false smut disease caused by $G$. phoenicis has been reported on date palm $(P$. dactylifera $)$ in Egypt and Brazil (Lima, 1996; Anonymous, 2003), Libya (Edongali, 1996), Kenya (Kung'u and Boa, 1997), Qatar (Abbas and Abdulla, 2004), Chile (Sepulveda et al., 2017), Yemen (Sattar et al.,

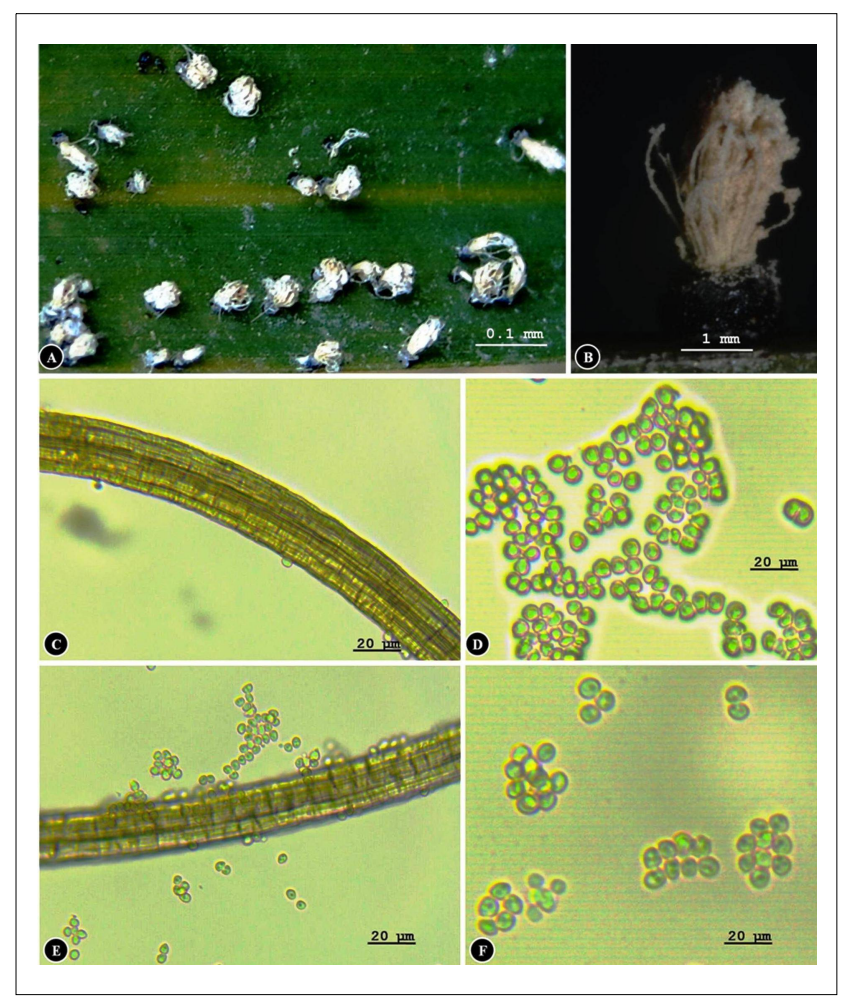

Fig. 2. Microscopic view of Graphiola phoenicis: A: Sori of $G$. phoenicis on leaves of $P$. sylvestris; B: A sorus showing typical black hard outer ring with filaments emerging through ostiole; $\mathbf{C} \boldsymbol{\&}$ D: Filament and spermatia of false smut associated with $P$. sylvestris observed under compound microscope; $\mathbf{E} \boldsymbol{\&} \mathbf{F}$ : Filament and spermatia of false smut associated with $P$. dactylifera observed under compound microscope.

2013) and many other regions from tropics and subtropics (Martinez, 1966; Tubaki and Yokoyama, 1971; Simon, 2004). The genus Graphiola (Exobasidiales, Basidiomycota) is known to parasitize palms from tropical and subtropical regions all around the world (Pipenbring et al., 2012). False smut caused by G. phoenicis is known to affect several palms including Phoenix dactylifera, P. canariensis, P. sylvestris and many other Phoenix sp. reported (Elliott, 2005). In India, Graphiola phoenicis associated with date palm is reported from Punjab (Sinha et al., 1970; Mehta et al., 1989) but, there are no records of occurrence of false smut on Indian date palm so far. Presently, the occurrence of false smut on Phoenix sylvestris is being reported for the first time from India.

\section{ACKNOWLEDGEMENTS}

First author (MKS) acknowledges the Council of Scientific and Industrial Research (CSIR), New Delhi, Government of India for awarding Research Associate Fellowship (No. ACK. No.:312077/2K17/1; File No. 09/119(0205)/

\section{REFERENCES}

Abbas, E.H. and Abdulla, A.S. 2004. First report of false smut disease caused by Graphiola phoenicis on date palm trees in Qatar. Plant Pathology 53:815.

Anonymous, 2003: CAB International. Crop Protection 
ompendium. Wallingford, UK: CABI Publishing.

Cole, G. 1983. Graphiola phoenicis: A taxonomic enigma. Mycologia 75:93-116.

Djerbi, M. 1983. Diseases of the Date Palm (Phoenix dactylifera). Baghdad, Iraq: FAO (Regional Project for Palm \& Dates Research Centre in the Near East $\&$ North Africa).

Edongali, E.A. 1996. Diseases of date palms (Phoenix dactylifera) of Libya. Arab Journal of Plant Protection 14: 41-43.

Elliott, M.L. 2005. Graphiola Leaf Spot (False Smut) on Palm. U.S. Department of Boa Agriculture, UF/IFAS Extension Service, University of Florida available at https://edis.ifas.ufl.edu/pdffiles/PP/ PP14000.pdf accessed on 11th May 2020.

Jain, P., Jain, S., Sharma, S. and Paliwal, S. 2018. Diverse application of Phoenix sylvestris: A potential herb. Agriculture and Natural Resources 52: 107-114.

Kung'u, J. and Boa, E. 1997. Kenya Checklist of Fungi and Bacteria on Plants and other Substrates. Egham, UK: International Mycological Institute.

Lima, M.F.1996. First Report of Graphiola Leaf Spot Caused by Graphiola phoenicis on Date Palm (Phoenix dactylifera) in the State of Pernambuco, in the Northeast of Brazil. Plant Disease 80: 823.

Martinez, A.P. 1966. False smut of palms. 43 Circular Plant Pathology, Florida Department of Agriculture. Division of Plant Industry.

Mehta, N., Gupta, P.C., Thareja, R.K. and Dang, J.K. 1989. Varietal behaviour and efficacy of different fungicides for the control of date palm leaf spot caused by Graphiola phoenicis. Tropical Pest Management 35:117-119.

Newton, C., Balthazard, M.G., Ivorra, S., Paradis, L., Pintaud, J.C. and Terral, J.F. 2013. Phoenix dactylifera and $P$. sylvestris in north Western India: a glimpse of their complex relationships. Palms 57:39-40.

Pipenbring, M., Nold, F., Trampe, T. and Kirschner, R. 2012. Revision of the genus Graphiola. New Hegwigia 94: 67-96.

Rao, G.R., Panemangalore, M. and Rajagopalan, R. 1970. Nutritional properties of neera and palm gur. Indian Journal of Nutrition and Dietetics 7: 44-52.

Sattar, M. H. A., Aulaqi, W. A. and Ibrahim, A. R. Y. 2013. Occurrence of false smut on date palm (Phoenix dactylifera L.) in the southern coastal plain of Yemen. Journal of Agricultural Science 5 (4): 2225.

Sepulveda, G., Arismendi, M., Huanca-Mamani, W., Cardenas-Ninasivincha, S., Salvatierra, R. and Latorre, B. 2017. Presence of false smut (Graphiola phoenicis (Moug. ex.Fr.) Poit. on canary date palm (Phoenix canariensis) on Easter Island, Chile. Ciencia e Investigacion Agraria 44 (3): 307-311.

Simon, G.W. 2004. Graphiola leaf spot (false smut). Pages 26-27. In: Compendium of Ornamental Palm Diseases and Disorders (Eds.: Elliott, M. L., Broschat, T. K., Uchida, J. Y. and Simone, G.W.). American Phytopathological Society, St. Paul, MN.

Sinha, M.K. Singh, R. and Jeyarajan, R. 1970. Graphiola leaf spot on date palm (Phoenix dactylifera): Susceptibility of date varieties and effect on chlorophyll content. Plant Disease Reporter 54: 617-619.

Tubaki, K. and Yokoyama, T. 1971. Cultural aspects of Graphiola phoenicis. Mycopathologia et Mycologia applicata 43: 49-60.

Yahia, E.M. and Kader, A.A. 2011. Date (Phoenix dactylifera L.). In: Postharvest Biology and Technology of Tropical and Subtropical Fruits (Ed.: Yahia, E. M.). Woodhead publishers; p.41-81. 